\title{
EFFECT OF MATERNAL DIETS DURING GESTATION AND LACTATION ON THE GROWTH OF OFFSPRING
}

\author{
TERUMI FUJII \\ Second Department of Internal Medicine, Kurume University School \\ of Medicine, Kurume, Japan
}

(Received for publication January 11, 1971)

\begin{abstract}
The effect of four types of maternal diet during gestation and lactation on the growth rate of progeny was investigated. These diets included Commercial Laboratory Chow (PC) and formulated diets with lactalbumin (LA), lactalbumin and $0.05 \%$ methionine (LM), or Alpha protein and $0.35 \%$ methionine $(\alpha \mathrm{M})$. Although similar birth weights were observed among all of these groups, progeny of mother fed ad lib $\alpha \mathrm{M}$-diet evidenced retarded growth after birth compared with the other three groups, among which no significant differences in growth of progeny were noted. However, there were marked differences in food intake in the mothers particularly during the lactation period. Food intake was largest in PC-group and smallest in $\alpha \mathrm{M}$-group, and same between LA and LM. This result reflected the poor growth of progeny and their larger value of food intake per $100 \mathrm{~g}$ body weight were similar amomg progeny of other three groups. Some aspects in relation to differences in food intake in mothers among these groups are discussed.
\end{abstract}

Investigations on human subjects and experimental animals have demonstrated the importance of an adequate maternal diet during gestation and lactation upon the successful termination of pregnancy and the growth of the offspring ${ }^{12}{ }^{2}$. In experiments performed in our laboratory, restriction of the maternal diet (Commercial Laboratory Chow) during gestation and lactation by $50 \%$ has resulted in subnormal-size progeny at birth whose body weight does not catch up with normal progeny despite ad lib feeding after weaning ${ }^{3)}$. Some investigators have published researches dealing with the effect of maternal diet containing varied levels of protein upon reproductive performance and growth of young for a short time period after birth ${ }^{1 / 2)}{ }^{4}$. However, few studies on this problem have been made extending the observation period. As an extention of my research into the problems of maternal diet I have studied the effect of four types of maternal diet fed ad lib during gestation and lactation upon the growth of progeny over the three months period after birth.

\section{EXPERIMENTAL}

Experimental diets. These are summarized in Table 1. Three formulated diets consisted of $20 \%$ lactalbumin or 
TABLE 1

Composition of diets

\begin{tabular}{c|c|c|c|c|c}
\hline Diet & Protein & Fat & Carbohydrate & Cal/g & Non-protein \\
\hline 1. Commercial Laboratory (PC) & $23.4^{2} \%$ & $3.78^{2} \%$ & $50.58^{2} \%$ & 3.3 & $2.36^{\text {Cal/g }}$ \\
Chow $^{1}$ & & & & & \\
2. Formulated diet with (LA) & $20^{3}$ & 4 & 70 & 3.78 & 3.16 \\
$\begin{array}{l}\text { 20\% lactalbumin } \\
\text { 3. Formulated diet with (LM) }\end{array}$ & $20^{3}$ & 4 & 70 & 3.78 & 3.16 \\
$\begin{array}{l}\text { 20\% lactalbumin and } \\
0.05 \% \text { methionine }\end{array}$ & 204 & 4 & 70 & 3.84 & 3.16 \\
4. Formulated diet with ( $\alpha \mathrm{M})$ \\
$\begin{array}{l}\text { Fo\% Alpha protein } \\
\text { 0.35\% and }\end{array}$
\end{tabular}

1. Purina Labolatory Chow, Ralston Purina Company, St.Louis.

2. Provided by the manufacturer.

3. According to manufacture's data, commercial lactalbumin contains $78 \%$ protein, so that this diet practically contains $15.6 \%$ protein.

4. According to manufacturers data, commercial Alpha protein contains $96.9 \%$ protein, so that this diet practically contains $19.4 \%$ protein.

5. Whitson Products, New York.

6. Industrial protein derived from soybean, Central Soya, Chicago.

Alpha protein, $70 \%$ sucrose, $4 \%$ corn oil, $2 \%$ cellulose, $4 \%$ salt mixture, 2.0 $\mathrm{ml}$ of fat-soluble vitamin solution, and $10 \mathrm{ml}$ of water-soluble vitamin solution per $\mathrm{kg}$ diet. Since addition of a small amount of methionine is known to improve biological value of several proteins, $0.05 \%$ methionine was added to LM-diet undertaking to obtain the best growth of progeny ${ }^{5)}$. Alpha protein is known to be deficient of methionine and so that $0.35 \%$ methionine was added to $\alpha \mathrm{M}$-diet.

Mating. Female rats from our colony of the original McCollum strain, approximately 3.5 to 4 months of age and 240 to $260 \mathrm{~g}$ in body weight, were mated from $10 \mathrm{P} . \mathrm{M}$. to $9 \mathrm{~A} . \mathrm{M}$. with male rats of same age, weighing 360 to $410 \mathrm{~g}$. Vaginal smears were examined daily and successful mating was determined by the presence of sperm in the smear. Pregnancy was confirmed by weekly increases in body weight.

\section{Care of pregnant females}

Smear positive female rats were isolated to individual cages on the morning successful mating was confirmed and were fed $30 \mathrm{~g}$ of each of four types of diet. As food consumptions increase after parturition, amount of food was raised to 40 to $60 \mathrm{~g}$, depending upon their food consumptions. These amounts always exceeded intake and represent ad lib feeding. Two weeks later pregnant rats were transfered to individual nesting cages and kept with their litters until the end of a four week lactation period. Three weeks after delivery all animals fed the experimental diets were shifted to Commercial Laboratory Chow. Food intakes were measured daily during the gestation and lactation periods.

Care of progeny. After parturition body weights of newborn pups were recorded within 14 hours and each week 
thereafter. After weaning all the pups were caged individually and fed ad lib Commercial Laboratory Chow. At 2.5 months of age food intakes were measured in the progeny for the subsequent three weeks. Food intake $/ 100 \mathrm{~g}$ body weight was calculated.

\section{RESULTS}

Fig. 1 illustrates the body weight changes of the mothers during gestation and lactation. During gestation no differences were noted in body weight gain among the groups, but after delivery the $\alpha \mathrm{M}$-group mothers began to lose weight concurrent with smaller increases in the food intake as compared with the three other groups. Three weeks after delivery, when all experimental diets were shifted to commercial ration the body weights of mothers in $\alpha \mathrm{M}$-group clearly began to increase despite continued lactation. This indicates that commercial ration is superior to $\alpha \mathrm{M}$-diet in supportign growth.

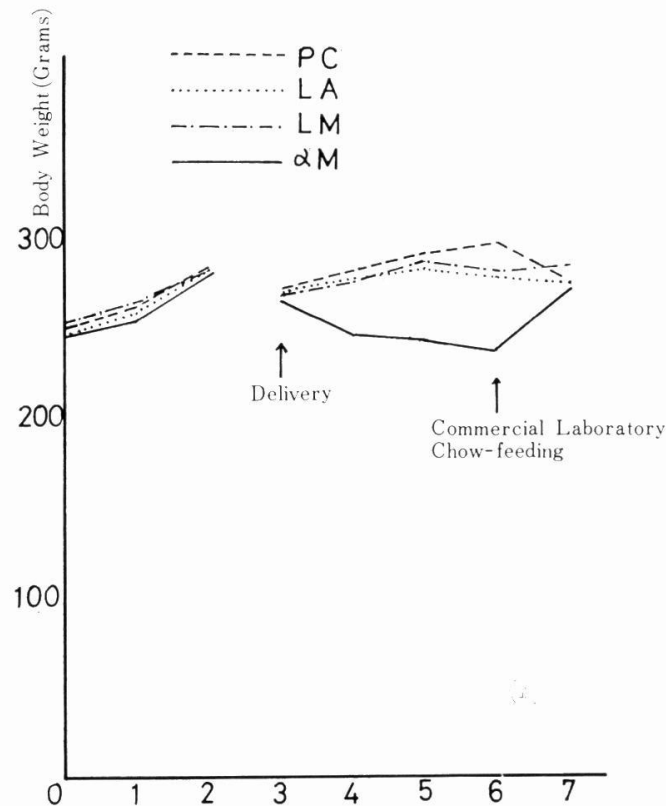

Time in weeks during gestation and lactation

Fig. 1 Body weight changes of mothers in each group during gestation and lactation. Mothers in $\alpha \mathrm{M}$-group began to gain body weight after administration of Commercial Laboratory Chow 3 weeks after delivery.

TABLE 2

Food intakes of mother rats in each group during gestation and lactation

\begin{tabular}{|c|c|c|c|c|c|c|c|c|}
\hline \multirow{2}{*}{$\begin{array}{c}\text { Maternal } \\
\text { diet }\end{array}$} & \multicolumn{3}{|c|}{ Gestation } & \multicolumn{3}{|c|}{ Lactation } & \multirow{2}{*}{ Gestation $^{3}$} & \multirow{2}{*}{ Lactation $^{3}$} \\
\hline & 1st week & 2nd week & 3rd week & 1st week & 2nd week & 3rd week & & \\
\hline $\mathrm{PC} \quad(4)^{2}$ & $\begin{array}{c}\mathrm{g} \\
15.0 \pm 1.0^{1}\end{array}$ & $\stackrel{\mathrm{g}}{17.1 \pm 0.96}$ & $\begin{array}{c}\mathrm{g} \\
20.9 \pm 1.7\end{array}$ & $\begin{array}{c}\mathrm{g} \\
30.3^{ \pm} \pm 3.4\end{array}$ & $\begin{array}{c}\mathrm{g} \\
46.6 \pm 1.3\end{array}$ & $\begin{array}{c}\mathrm{g} \\
53.2 \pm 5.2\end{array}$ & $\begin{array}{c}\mathrm{g} \\
17.7\end{array}$ & $\begin{array}{c}\mathrm{g} \\
43.4\end{array}$ \\
\hline $\mathrm{L} \mathrm{A}$ & $14.2 \pm 0.3$ & $14.6 \pm 0.8$ & $15.4 \pm 1.9$ & $18.7 \pm 0.5$ & $32.9 \pm 0.9$ & $38.9 \pm 2.7$ & 14.7 & 30.1 \\
\hline L M & $13.7 \pm 3.2$ & $14.8 \pm 0.6$ & $15.0 \pm 0.4$ & $18.5 \pm 1.3$ & $35.0 \pm 2.1$ & $41.9 \pm 4.1$ & 14.5 & 32.8 \\
\hline$\alpha \mathrm{M}$ & $13.9 \pm 1.0$ & $15.2 \pm 1.8$ & $14.4 \pm 1.1$ & $18.2 \pm 0.6$ & $25.1 \pm 0.4$ & $28.9 \pm 0.8$ & 14.5 & 24.1 \\
\hline
\end{tabular}

1. Mean $\pm S E$

2. No. of rats (Male)

3. average of each group for whole of gestation or lactation

$p$ values during gestation

$P C$ vs $L A<0.05$

$P C$ vs $L M<0.05$

$P C$ vs $\alpha M<0.05$ $p$ values during lactation

$P C$ vs $L A<0.01$

$P C$ vs $L M<0.05$

$P C$ vs $\alpha M<0.01$

$\alpha M$ vs $\frac{L A+L M}{2}<0.01$ 
Among all groups the food intake, as given in Table 2, was largest in PCgroup, smallest in $\alpha \mathrm{M}$-group, and approximately same in LA and LMgroups. Notably, during lactation period a marked difference in food intake between PC and $\alpha \mathrm{M}$-groups was observed and the latter was approximately onehalf the former. Food intake $/ 100 \mathrm{~g}$ birth weight was also shown in Table 3.

TABLE 3

Food intake/10og body weight of mother rats during gestation and lactation

\begin{tabular}{|c|c|c|c|c|c|c|}
\hline \multirow{2}{*}{$\begin{array}{l}\text { Maternal } \\
\text { diet }\end{array}$} & \multicolumn{3}{|c|}{ Gestion } & \multicolumn{3}{|c|}{ Lactation } \\
\hline & 1st week & 2nd week & 3rd week & 1st week & 2nd week & 3rd week \\
\hline $\mathrm{PC} \quad(4)^{1}$ & $\begin{array}{l}\mathrm{g} \\
6.0^{2}\end{array}$ & $6.3^{g}$ & $-^{g}$ & $\begin{array}{r}\mathrm{g} \\
11.1^{-}\end{array}$ & 16. $3^{\mathrm{g}}$ & $\begin{array}{r}\mathrm{g} \\
18 .{ }^{1}\end{array}$ \\
\hline L A & 5.7 & 5.4 & - & 6.9 & 11.8 & 13.9 \\
\hline $\mathrm{L} \mathrm{M}$ & 5.4 & 5.5 & - & 6.8 & 12.5 & 14.8 \\
\hline$\alpha \mathrm{M}$ & 5.5 & 5.6 & - & 7.2 & 10.3 & 12.1 \\
\hline
\end{tabular}

1 No. of rats

Table 4 presents the similar birth weights of the pup in each group. After birth, however, the growth rate of pups in the $\alpha \mathrm{M}$-group was retarded as illustrated in Fig. 2. The other three groups maintained a normal grow th rate. Notably, LA and LM groups were characterized in normal growth of their progeny despite of less food consumption by mothers.

TABLE 4

Effect of maternal diet on the growth of progeny

\begin{tabular}{|c|c|c|c|c|c|c|c|c|c|c|}
\hline \multirow{2}{*}{ Diet } & \multirow{2}{*}{$\begin{array}{l}\text { No. of } \\
\text { litters }\end{array}$} & \multirow{2}{*}{$\begin{array}{l}\text { No. of pups } \\
\text { born alive }\end{array}$} & \multirow{2}{*}{\multicolumn{2}{|c|}{ Birth weight }} & \multicolumn{6}{|c|}{ Mean body weight } \\
\hline & & & & & At & age of 3 & veeks & At & age of 10 & weeks \\
\hline P C & 4 & 43 & $\begin{array}{l}\hat{0} \\
\text { 우 }\end{array}$ & $\begin{array}{l}\text { g. } \\
6.2 \pm 0.2^{1} \\
6.1 \pm 0.1\end{array}$ & $\begin{array}{l}\hat{0} \\
\stackrel{+}{+}\end{array}$ & $\begin{array}{c}\mathrm{g} . \\
34.1 \pm 1.8 \\
31.3 \pm 1.8\end{array}$ & $\begin{array}{l}(10)^{2} \\
(10)^{2}\end{array}$ & $\begin{array}{l}\hat{\circ} \\
\stackrel{\circ}{+}\end{array}$ & $\begin{array}{c}\text { g. } \\
304 \pm 10.1 \\
200 \pm 5.4\end{array}$ & $\begin{array}{l}(9) \\
(10)\end{array}$ \\
\hline L A & 5 & 53 & $\begin{array}{l}\hat{o} \\
\stackrel{+}{+}\end{array}$ & $\begin{array}{l}6.4 \pm 0.08 \\
6.1 \pm 0.06\end{array}$ & $\begin{array}{l}\hat{o} \\
\stackrel{+}{+}\end{array}$ & $\begin{array}{l}36.7 \pm 6.5 \\
36.3 \pm 1.7\end{array}$ & $\begin{array}{l}(19) \\
(19)\end{array}$ & $\begin{array}{l}\hat{\circ} \\
\stackrel{0}{+}\end{array}$ & $\begin{array}{l}296 \pm 6.7 \\
194 \pm 4.5\end{array}$ & $\begin{array}{l}(15) \\
(17)\end{array}$ \\
\hline L M & 4 & 44 & $\begin{array}{l}\text { 定 } \\
\text { ơ }\end{array}$ & $\begin{array}{l}6.4 \pm 0.08 \\
6.1 \pm 0.1\end{array}$ & $\begin{array}{l}\hat{O} \\
\text { o }\end{array}$ & $\begin{array}{l}39.6 \pm 2.1 \\
42.3 \pm 1.2\end{array}$ & $\begin{array}{r}(16) \\
(8)\end{array}$ & $\begin{array}{l}\hat{\circ} \\
\text { ơ }\end{array}$ & $\begin{array}{l}303 \pm 8.5 \\
197 \pm 5.9\end{array}$ & $\begin{array}{r}(15) \\
(8)\end{array}$ \\
\hline$\alpha \mathrm{M}$ & 4 & 42 & $\begin{array}{l}\text { 昘 } \\
\text { 우 }\end{array}$ & $\begin{array}{l}6.5 \pm 0.09 \\
6.2 \pm 0.1\end{array}$ & $\begin{array}{l}\hat{o} \\
\text { o }\end{array}$ & $\begin{array}{l}22.2 \pm 1.4 \\
23.3 \pm 1.5\end{array}$ & $\begin{array}{l}(14) \\
(13)\end{array}$ & $\begin{array}{l}\hat{o} \\
\stackrel{0}{+}\end{array}$ & $\begin{array}{l}236 \pm 9.4 \\
175 \pm 7.4\end{array}$ & $\begin{array}{l}(10) \\
(10)\end{array}$ \\
\hline
\end{tabular}

1 Mean $\pm S E$

Table 5 summarizes the food intakes of progeny in each group. Although the consumption of food by progeny in $\alpha \mathrm{M}$-group were somewhat smaller than that of other three groups, food intake $/ 100 \mathrm{~g}$ birth weight of former group was significantly larger than others as shown in Table 5. This result 


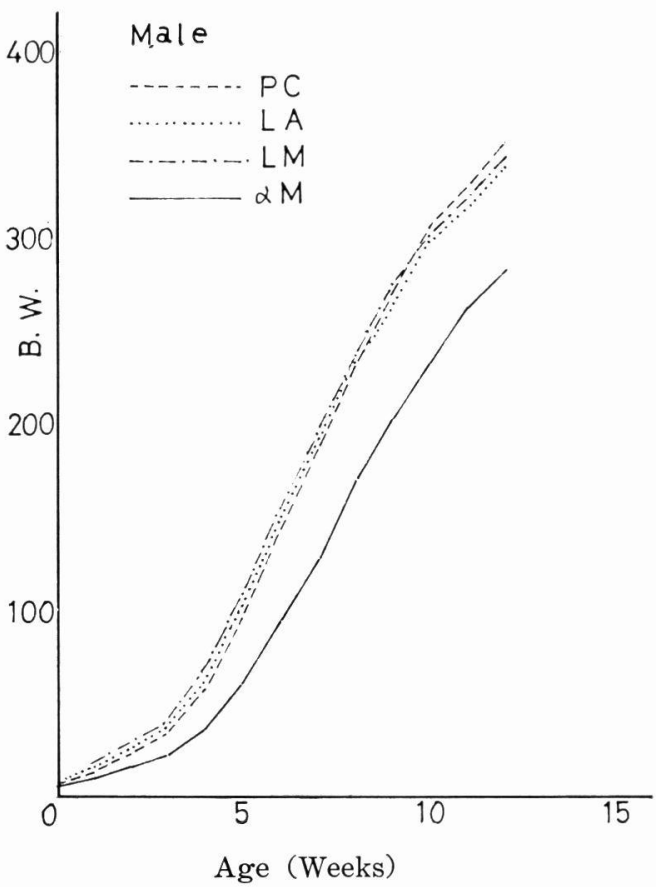

Fig. 2 Growth rate of male progeny in each group. 3 weeks after birth Commercial Laboratory Chow was given to each progeny.

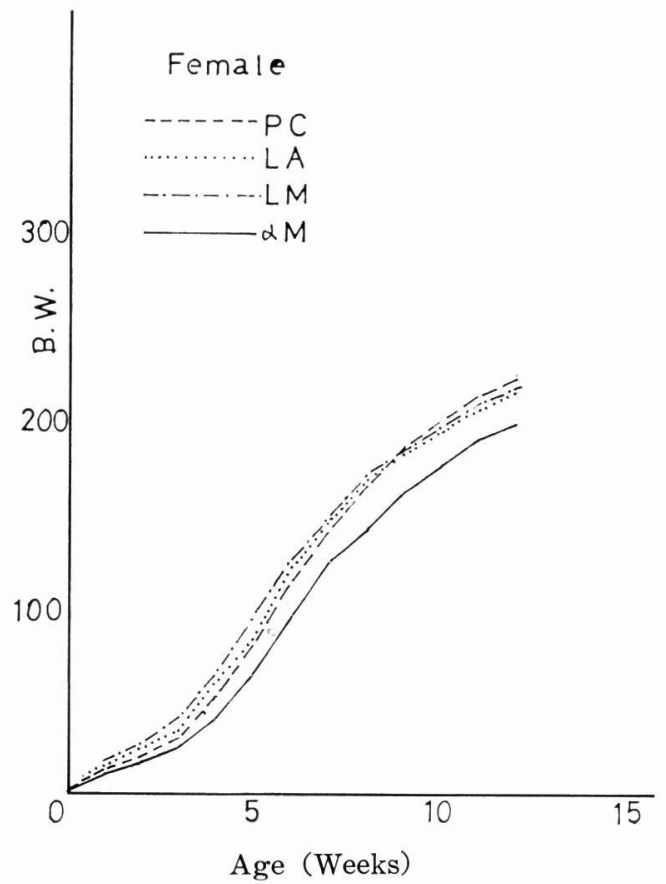

Fig. 3 Growth rate of female progeny in each group. 3 weeks after birth Commercial Laboratory Chow was given to each group.

TABLE 5

Food intake and food intake/100g body weight of progeny in each group

\begin{tabular}{c|c|c|c|c|c}
\hline \multirow{2}{*}{$\begin{array}{c}\text { Maternal } \\
\text { diet }\end{array}$} & $\begin{array}{c}\text { No. of } \\
\text { rats }^{1}\end{array}$ & $\begin{array}{c}\text { Age of rats at } \\
\text { the beginning } \\
\text { of experiment }\end{array}$ & 1st week & 2nd week & 3rd week \\
\cline { 3 - 6 } & 5 & 2.5 Months & $21.7 \pm 0.4^{2}$ & $21.5 \pm 0.6$ & $21.3 \pm 0.6$ \\
P C & 5 & 2.5 Months & $20.4 \pm 0.3$ & $20.7 \pm 0.3$ & $20.8 \pm 0.4$ \\
L A & 7 & 2.5 Months & $20.9 \pm 0.6$ & $20.4 \pm 0.5$ & $20.4 \pm 0.5$ \\
L M & 6 & 2.5 Months & $18.9 \pm 0.6$ & $19.0 \pm 0.4$ & $18.4 \pm 0.5$ \\
$\alpha$ M & 7 & 2.5 &
\end{tabular}

\begin{tabular}{|c|c|c|c|c|c|c|}
\hline & & \multicolumn{3}{|c|}{ Food intake/100 g b. wt. } & \multirow{2}{*}{$\begin{array}{l}\text { Average of food } \\
\text { intake per } 100 \mathrm{~g} \\
\text { b. wt. during } \\
\text { whole period }\end{array}$} & \multirow{2}{*}{$\begin{array}{l}\text { Avearge of b. wt. } \\
\text { during whole } \\
\text { period }\end{array}$} \\
\hline & & 1st week & 2nd week & 3rd week & & \\
\hline $\mathrm{PC}$ & 5 & $\begin{array}{c}\mathrm{g} . \\
6.2 \pm 0.1\end{array}$ & $\begin{array}{c}\mathrm{g} . \\
5.8 \pm 0.1\end{array}$ & \begin{tabular}{c|}
$\mathrm{g}$. \\
$5.6 \pm 0.1$
\end{tabular} & $\begin{array}{c}\mathrm{g} \\
5.9 \pm 0.1\end{array}$ & $\underset{368}{\mathrm{~g}}$. \\
\hline $\mathrm{LA}$ & 7 & $6.3 \pm 0.2$ & $6.0 \pm 0.1$ & $5.8 \pm 0.1$ & $6.0 \pm 0.1$ & 342 \\
\hline $\mathrm{LM}$ & 6 & $6.4 \pm 0.3$ & $5.9 \pm 0.1$ & $5.7 \pm 0.1$ & $6.0 \pm 0.1$ & 345 \\
\hline$\alpha \mathrm{M}$ & 7 & $7.4 \pm 0.3$ & $6.9 \pm 0.3$ & $6.3 \pm 0.1$ & $6.8 \pm 0.5$ & 277 \\
\hline \multicolumn{7}{|c|}{${ }^{1}$ Male rats $\quad{ }^{2}$ Mean $\pm S E$} \\
\hline
\end{tabular}


represents a similarity between progeny in the $\alpha \mathrm{M}$-group and progeny produced by mother rats underfed during gestation and lactation as reported from this laboratory ${ }^{6)}$.

\section{DISCUSSION}

These data indicate that among the three groups excluding $\alpha \mathrm{M}$-group general characteristics were similar with the exception of larger food consumption by PC-group during gestation and lactation periods. Particularly the similarity in every respect was noted between LA and LM-groups and there- fore LM-group was included in LAgroup for purposes of discussion unless otherwise mentioned. It is of great interest that there are such significant differences in food intake among these groups. As shown in Table 6, however, when we see this phenomenon in terms of calorie intake between $\mathrm{PC}$ and LA groups, the difference from the total calorie point of view becomes smaller but still significant during lactation and not significant during gestation.

On the other hand, from non-protein calorie point of view no significant differences in calorie intake between PC and LA-groups were noted during lactation and gestation.

TABLE 6

Caloric intakes of mother rats during gestation and lactation

\begin{tabular}{|c|c|c|c|c|c|c|c|c|}
\hline \multirow[b]{2}{*}{$\begin{array}{l}\text { Maternal } \\
\text { diet }\end{array}$} & \multicolumn{2}{|c|}{ Gestation } & \multicolumn{2}{|c|}{ Lactation } & \multicolumn{2}{|c|}{ Gestation } & \multicolumn{2}{|c|}{ Lactation } \\
\hline & $\begin{array}{l}\text { Food } \\
\text { intake } \\
\quad \mathrm{g}\end{array}$ & $\begin{array}{c}\text { Caloric } \\
\text { intake } \\
\text { cal }\end{array}$ & $\begin{array}{l}\text { Food } \\
\text { intake } \\
\qquad \mathrm{g}\end{array}$ & $\begin{array}{c}\text { Caloric } \\
\text { intake } \\
\text { cal }\end{array}$ & $\begin{array}{l}\text { Food } \\
\text { intake } \\
\mathrm{g}\end{array}$ & $\begin{array}{c}\text { Non-protein } \\
\text { caloric } \\
\text { intake } \\
\text { cal } \\
\end{array}$ & $\begin{array}{c}\text { Food } \\
\text { intake } \\
\mathrm{g}\end{array}$ & $\begin{array}{c}\text { Non-protein } \\
\text { caloric } \\
\text { intake } \\
\text { cal }\end{array}$ \\
\hline $\mathrm{PC}$ & 17.7 & 58.3 & 43.4 & 143 & 17.7 & 41.8 & 43.4 & 102.4 \\
\hline$\frac{\mathrm{LA}+\mathrm{LM}^{1}}{2}$ & 14.7 & 55.6 & 30.8 & 116.4 & 14.7 & 46.5 & 30.8 & 97.3 \\
\hline
\end{tabular}

1 General pictures in every respects between $L A$ and $L M$-group were almost same, so that the average was taken to obtain more accuracy.

The appetite is known to be involved in many complicated factors ${ }^{7}$. In my experiments, however, all experimental conditions except for diet were the same, so that the factors responsible for these differences in food intake could be sought in the diet itself. Since commercial ration, known to be good diet for growth for experimental rats, is composed of various types of protein, it is difficult to compare this diet with another one containing lactalbumin. However, so far as protein composition is concerned, as shown in Table 7, lactalbumin is more abundant in essential amino acids than commercial ration. On the basis of amino acid composition and energy content in both diets, the following assumption would be allowed. It seems that the group fed commercial ration with less quantity in essential amino acids but slightly higher protein level and lower carbohydrate level compared with LA-diet containing lactalbumin, one of the best quality proteins, consumes larger amounts of food to meet increased requirement of amino acids and energy for increased produc- 
TABLE 7

Amino acid composition of Commercial Laboratory Chow and LA-diet

\begin{tabular}{c|c|c}
\hline Amino acids & Commercial ration & LA-diet $^{3}$ \\
\hline Lysine & $1.27^{1} \%$ & $1.7^{1 \%}$ \\
Methionine + cystine & 0.61 & 1.09 \\
Tryptophane & 0.22 & 0.4 \\
Leucine & 1.40 & 1.94 \\
Isoleucine & 1.03 & 1.2 \\
Threonine & 0.78 & 0.97 \\
Valine & 1.02 & 1.09 \\
\hline
\end{tabular}

1 All amino acids were expressed as per cent of ration.

2 These data were provided by the manufacture.

Ralson Purina Company, St. Louis.

3 These data were calculated on the basis of manufacturers data. Vhitson Products, New York.

tion of tissue protein during gestation and lactation.

On the other hand, my data indicated remarkable differences in food intake between $\alpha \mathrm{M}$ and other three groups during lactation, although no marked differences were noted during gestation. This result is reflected gradual deleterious growth of progeny after birth and body weight decrease of mothers for $\alpha \mathrm{M}$-group despite successful pregnant performance and normal birth weight. It was shown that weight loss of mothers in $\alpha \mathrm{M}$-group were not due to disease, since they increased body weight without exception soon after diet was shifted to commercial ration at fourth week after delivery despite continued lactation. However, the growth of weanlings of $\alpha \mathrm{M}$-group could not attain the normal growth level until age of 14 weeks despitte the supply of commercial ration ad lib. Alpha protein is known to be deficient in some kinds of amino acids such as methionine and lysine. Despite addition of methionine to $\alpha \mathrm{M}$-diet, the growth of progeny in this group was unexpectedly retarded.
Block et al. reported that the nutritive value for young rats of soybean protein could be slightly improved by the addition of cystine, methionine but that the addition of lysine in small quantities was not beneficial and in larger amounts actually suppressed growth ${ }^{8)}$. Moreover, these progeny showed larger food intake/100 $\mathrm{g}$ body weight than other three groups. This result is in agreement with restricted progeny with subnormal efficiency of food utilization produced by our laboratory, suggesting the importance of nutrition of mothers during gestation and lactation, particularly during lactation. Because although normal birth weight was observed in $\alpha \mathrm{M}$-group despite the supply of $\alpha \mathrm{M}$ - diet, growth of progeny after birth was retarded. It could not be explained at present why although mothers receiving $\alpha \mathrm{M}$ diet consumed the same amount of food as LA group during gestation, they failed to attain the same level as LAgroup following gestation despite the remarkably increased requirement for nutrients. 


\section{ACKNOWLEDGMENT}

The author wishes to thank Prof. B. F. Chow at Department of Biochemistry, Johns Hopkins University for his encouragement and advice.

\section{LITERATURE CITED}

1) Slonaker, J. R.: The effect of different percents of proteins in the diet in successive generations. Amer. J. of Physiol., 123, 526, 1938.

2) Nelson, M. M. and Evans, H. M. : Relation of dietary protein levels to reproduction in the rat. J. Nut., 51, 71, 1953.

3 ) Chow, B. F. and LeE, C. J. : Effect of dietary restriction of pregnant rats on body weight gain of the offspring. J. Nut., 82, 10, 1964.
4) Pike, R. L., Suder, H. B. and Ross, M. L. : The influence of protein and energy intakes upon nitrogen retention in the pregnant rat. J. Nut., 52, 297, 1954.

5) Block, R. J. and Mitchell, H. H.: The correlation of the amino acid composition of proteins with their nutritive value. Nut. Abstr. and Rev., 16, 249, 1946.

6) LeE, C. J. and Chow, B. F. : Protein metabolism in the offspring of underfed mother rats. J. Nut., 87, 439, 1965.

7) Beaton, G. H. and McHenry, E. W. : Regulation of food intake. Nutrition, 1, 1, 1964.

$8)$ Block, R. J., Anderson, D. W., Howard, H. W. and BAUER, C. D. : Effect of supplementing soybean proteins with lysine and other amino acids. AMA J. of Diseases of Children 92, 126, 1956. 